\title{
Critical Factors in Process Quality of Engineering Construction Projects during Building Design Phase
}

\author{
Abdul Haseeb Aamir Sheikh',2| Tawiah Kwatekwei Quartey-Papafio ${ }^{3}$ | \\ Muhammad Ikram ${ }^{4,1, *} \mid$ Rana Mamoon Ahmad ${ }^{5,1}$ \\ ${ }^{1}$ Institute for Grey Systems and Decision Sciences, GreySys Foundation, Lahore, Pakistan \\ ${ }^{2}$ Department of Civil Engineering, Fatima Fertilizer, Multan, Pakistan \\ ${ }^{3}$ College of Economics and Management, Nanjing University of Aeronautics and Astronautics, Nanjing, China \\ ${ }^{4}$ School of Business Administration, Al Akhawayn University in Ifrane, Ifrane, Morocco \\ ${ }^{5}$ Department of Civil Engineering, National University of Sciences and Technology, Islamabad, Pakistan \\ *Corresponding author: i.muhammad@aui.ma
}

Received 6 April 2021; Revised 25 May 2021; Accepted 25 May 2021

\begin{abstract}
Quality in construction is an important topic in the design phase due to the quick change in technological advancement. The current study focuses on the identification, measurement, and analysis of the critical elements which impact the process quality of building construction projects during the design stage in Pakistan. Elements were graded using the conservative Relative Importance Index (RII) and Grey Absolute Decision Analysis (GADA). The findings indicate that during the design phase, the critical element impacting process quality is the quality of codes and standards and was facilitated using a questionnaire survey. Similarly, the teamwork of parties in design firms and constructability analysis of the design are key factors during the design phase in Pakistan. Measures for the improvement of process quality in Pakistan were suggested. The building construction projects need to be modified to cover the important aspects of constructability analysis, continuous working on training programs, and many other related activities. These are performed through a proper commitment to continuous quality improvement in building construction projects. The results are important for improving process quality during the construction projects' design phase.
\end{abstract}

Keywords: Civil engineering; construction; grey system theory; project design; quality process

\section{Introduction}

Gone are the days when project management was viewed as a threat to established lines of authority and thus to the traditional way of managing organizational tasks as today it has been widely recognized as a competitive weapon to provide superior quality and services to the clients (Mahmoudi et al., 2020; Kerzner, 2014). Quality is not a new concept for construction project managers. For construction companies, quality is considered the satisfaction of the customers and as the component that tends to fulfill the requirements within the specified budget. In the construction sector, quality control is considered as client satisfaction, cost, and time of obtaining 
anticipated quality. Quality is a paramount requirement for every stakeholder in the construction industry. The construction quality of projects depends on process quality during various construction phases. According to Arditi and Gunaydin (1998), several elements impact the process quality of building construction. These elements include general elements like employee training, teamwork, the interest of management and top management in promoting quality, etc., building industry-specific elements like the selection of appropriate firms, quality of drawings and specifications, adequacy of supervision, etc. Quality is one of the crucial matters for the construction industry, where clients' requirements are a certification of quality (Chung, 2002). Project quality management must address both the product quality and process quality of the project. One must comprehend the difference between process quality and product quality. Process quality represents the quality and standard of a process that indicates the product is up to par or not (Nagasaku \& Oda, 1965), whereas the product quality suggests the quality of the elements, which are in direct association with the product itself. Delivering quality projects is extremely important for a project management firm to produce satisfied clients and thus the firm more profitable (Javed \& Liu, 2018).

Evaluation of the critical success factors (CSFs) in project environment has received due attention by scholars for years, especially in the developing countries, where the studies on the CSFs of projects and industries have been seeking attention at least since the 1990s. Huirne et al. (1997) evaluated the CSFs for the dairy farmers in the Netherlands and Michigan (USA). Roos et al. (1999) assessed the Critical factors to bioenergy implementation in the USA and some European countries. With the globalization and quests for new markets in the developing world, the projects and industries in the developing countries also got some attention, especially in the last few years. For instance, Banihashemi et al. (2017) investigated the CSFs for integrating sustainability into construction project management practices in developing countries. Mashwama et al. (2017) assessed the critical success factor for reducing cost of poor quality in construction projects in Swaziland. Maqbool and Sudong (2018) studied the CSFs for renewable energy projects; empirical evidence from Pakistan. Batool and Abbas (2017) studied reasons for delay in selected hydropower projects in Khyber Pakhtunkhwa, a province of Pakistan. Li et al. (2019) present a very thorough review of CSFs (CSFs) for green building projects. They identified "Designers' performance" as one of the $28 \mathrm{CSF}$. If one reviews the literature,, one finds that evaluating the critical factors in process quality of construction projects during the building design phase has never been done. Furthermore, if one digs deeper in the literature one finds studies involving CSFs of Pakistani projects have rarely been executed, let alone in the crucial context of designing. It has been observed that the construction industry of Pakistan and India has certain distinguishing characteristics compared with other developing countries. Each region has its own characteristic, and thus, the development of the economy and its heavy industries like construction and building industries always take place in its certain circumstances. The development of construction is always made in accordance with the environment of a country, weather, availability of raw material, and many other related attributes that are considered to have a bearing impact on the designing, processing and execution of construction industry projects. Even soft factors also play their influence e.g., employee behavior, attitude, motivational level, team management and training and development sessions. Studies (e.g., Belout and Gauvreau, 2004; Strain \& Preece, 1999) have confirmed the role of human and individual factors' role in project success and deliverables. The role of human factors in organizational design and management has also been widely recognized (Carayon et al., 2012). However, the critically important factors in construction projects during the building design phase were question none of the existing studies have fully answered. This can be attributed to two reasons; (a) the data collection during the project designing phase is hard to obtain in the countries like Pakistan where effective data management practices are fragile; (b) absence of policies that can ensure that project data is routinely recorded and transparently reported for future lessons, and avoiding mistakes in future.

In the context mentioned above, and the gap we just reported, the current study was initiated, with the primary aim of identification, measurement, and analysis of the critical elements that 
directly impact the process quality of building construction projects during the design phase in developing countries.

\section{Literature Review}

\subsection{Process Quality}

Aristotle thought that there is some good at which all actions aim (Ostenfeld, 1994). Engels argued that each action transforms quantity into quality, resulting from the quantitative change associated with the movement of the object experiencing the transformation (Stalin, 1976: p. 839). Quality has remained a topic of interest among scholars and practitioners alike for ages in its different forms. However, still, it is hard to define the term "quality," and there is no one definition that fits all purposes (Chan et al., 2006; Javed et al., 2019). It is, in fact, difficult to explain quality meaningfully and precisely in the case of building construction (Low \& Goh, 1994). In project management literature, quality has been defined as "a continuous function of duration and cost" (Mahmoudi \& Javed, 2020). As Heravitorbati et al. (2011) expressed, quality is the satisfaction of requirements of all the stakeholders engaged in construction projects. According to Juran (1988), quality is a good or flawless facility. Quality is also defined as the conformity of the constituted requirements (Burati et al., 1992). Measuring the quality of a product or good is relatively easier than measuring the quality of services because of the intangibility associated with services (Javed and Liu, 2018).

Process quality is an aspect of management technique under Total Quality Management (TQM) which was first developed, applied and accepted by the Japanese construction industry in the 1970s and has subsequently been used to improve productivity, lessen product cost and increased product reliability (Arditi \& Gunaydin, 1997). Jaber et al. (2018) explained the purpose of process quality: to reduce the occurrences of production or to assemble processes going out of control. Every phase of a project undergoes a process that must observe quality at every level. The quality of every process is key to the attainment of the total quality of the project. With this in mind, the process quality engineers the entire quality desired to be achieved. All elements in the process quality chain must not be overlooked as it might hinder the probability of reaching the utmost quality. In line with construction, for example, the erection of a strong and quality pillar depends not only on the quality and proportion of the components of concrete used but also the quality of the process by which they underwent.

The determination of the quality of a structure relies on adequate supervision and management of all activities undertaken during the construction project, which in simple terms is known as process quality. Optimized results are highly obtainable by evaluating projects and products through process quality. A process quality control approach was used to verify beam alignment in laser operations (Mourtzis et al., 2018), which provided grounds for laser suppliers to shift business models to servitization. The elements such as management leadership, strategic planning, employee empowerment, and quality training are associated with TQM, which reflects the positive relation total quality management has with performance (Sahoo \& Yadav, 2018). The construction industry is indifferent to applying quality management to improve performance, but the quality performance of a product or service cannot be checked independently, quality must be created with the process of the product (Ulewicz \& Nový, 2019). The philosophy of attaining quality in improving products and services is generating breaking ground roots in a wide range of industries and sectors. To reach the quality of service in the education sector, Militaru et al. (2013) employed the principle of TQM in order to achieve excellence in the second cycle and university level. They established that a holistic approach of TQM in education must induct the seven elements: philosophy, vision, strategy, aptitudes, resources, rewards, and organization, which is expected to long-duration as productive results in education are seen in the future terms. A study conducted in Unite Arab Emirate evaluated TQM, which is seldom used in mechanical, electrical and plumbing and a conventional management approach thus the status quo procedures (Small \& Al, 2017). The research concluded that TQM has a significate impact on productivity and project progress. 
Process quality, therefore, measures the overall quality of products and services more realistic to be achieved.

\subsection{Importance of Good Project Design for Project Success}

The success of a project in relatively associated with its planning and design pattern. A good project design is significant to satisfy an expected objective as it stands to be a pillar and framework of the holistic project. A project design is characterized by a group of unique designers who interdependently captivates the priority and sequence of a good design process (Mujumdar \& Maheswari, 2018). This bridges the gaps and ascertains the aim of the project. Iterations are inevitably looking at the complexity of a project such as construction. With the high level of uncertainty related to the requirement of a project, an iteration based on solution-oriented within the project design phase enables understanding and adapt solution to meet defined goal of the project (Gebhardt et al., 2019). In the design of a project where adequate iterations are observed, quality is achieved in the project design.

All stages in a project design phase are very vital to undergo in order to prevent project failure as clarity is given on all contextual factors that plan an essential roll, such as resources and structures (Stritter et al., 2018). Tjell and Bosch (2015) enlightened on visualization management as one important aspect in project design which is rarely known in the construction industry yet supports communication and mutual understanding during design. They also concluded that all actors in design teams actively engage and become more self-going by visual management. In other words, a good project design increases the productivity and quality of the project by making appropriate decisions. Also, the advantage of $2 \mathrm{D}$ or $3 \mathrm{D}$ visualization provides a vivid perspective on the outlook of the expected design, which is more flexible and easily understood by creating intense and direct relationship between the design and customers (Bieger \& Carvalho, 2015).

Looking at the health sector, design projects have gone a long was to improve the quality of care at the hospital. After an evaluation by project design, the German University Hospital developed an integrated care unite for children with cancer (Stritter et al., 2018). Interventions have been made for patients to be treated appropriately to aid in quality health care. Rahmat et al. (2012) studied the impact and development on students as they accomplish an effective project design with the knowledge of mathematics and science to resolve engineering problems. Skills such as teamwork spirit, communication, engineering and critical thinking are highly developed which advances the students capacity. The high academic success achieved reflects the satisfaction that boost design capability and creativity (Dizdar, 2015).

\subsection{Construction Industry and Quality Management in Pakistan}

In Pakistan, the construction industry plays an active role in economic development and reduces unemployment. The construction industry $(\mathrm{CI})$ provides many job opportunities with many business enterprises and other industries. The construction industry has good connections and strong relational impact to approximately forty (40) building and construction material industries, design engineering firms, and finance organizations. Community development is also at a rise which goes a long way to lessen penury by creating earnings for poverty-stricken families. During the year 2003-2004, about 5.3-5.5\% of the working population, thus 2.3 million people, benefited from the construction industry (Khan, 2008).

Farooqui et al. (2008) implemented TQM principles to investigate the behavior of contractors in the construction industry through questionnaires and direct interviews. The study highlighted the following to be the problems that influence a contract's behavior thus inadequate knowledge on quality, lacking construction industry education and the varying characteristics of The construction industry, and being corrupt. The contractors are overwhelmed by the approach of TQM, so they are reluctant to adopt the technique. Conclusions further stated that for quality improvement, it was crucial to focus on managerial leadership skills and be committed to employees' education and quality. 
The key importance of Total Quality Management (TQM) is clearly discussed by Memon et al. (2013), a typical case study that describes the implementation of TQM system in Pakistan. The scholars explained that with the implementation of TQM, there is improved market share, performance is enhanced, attention is drawn to top management activities, and meeting the needs at the lower level. It further builds a good relationship between suppliers and customers where by the satisfaction of the client is met. TQM plays the role of measuring construction quality. Despite the benefits of the TQM technique, many loopholes hinder its effective practice. Many scholars have investigated the barriers that limit TQM, which were related to human resources, organizational culture, methods of training, management and attitudes towards quality, among others (Amar \& Mohd Zain, 2002). Literature shows that quality is well known to experts in the field of construction in Pakistan, but however, there is less research on the potency of process quality and how it improves productivity. The study investigates quality management principles and its primary elements that improve construction projects during the design phase.

The free market model is being allowed in more countries, and these countries are opening up their borders for trading and investment; as a result, worldwide competition is becoming a greater concern (Lee, 2002). To remain in the struggle, an organization's main business strategy has to emphasize on strategic remuneration through the development of its business brilliance and enactment. Quality management has now become an indispensable and completely universal planned strength in the current tempestuous and vibrant professional world (Temtime, 2003). The growing amount of universal struggle has made this quality management a must requirement for existence. Due to business brilliance and greater performance, companies will become more economical and this is caused by adopting sound quality management practices (Lee, 2002).

The two aspects of construction project quality are process quality and product quality. A designer who lacks technical knowledge, especially concerning process quality in design, may develop faulty designs that may pose constructability issues later in the project's execution phase. It is unlikely to reach the quality of a construction project without considering the quality of every phase's processes. All actors or designers are to inclusively put into use all elements that aid quality in executing their expertise in the construction project.

\section{Research Methodology}

\subsection{The Research Instrument}

Numerous aspects of process quality impact building construction projects, e.g., employee training, teamwork, the interest of management and top management in promoting quality, and building industry-specific elements like selecting appropriate firms, quality of drawings, specifications, adequacy of supervision, etc. The data collection tool adapted in the current study was inspired by Arditi and Gunaydin $(1997 ; 1998 ; 1999)$. Here it should be mentioned that it is the first time this tool has been applied in Pakistani projects' context. An alien tool can be applied in a new market if it shares certain characteristics (e.g., the construction sector of different countries shares some common characteristics), its validity is confirmed through appropriate response rate, and the results are rationale. This reasoning can be confirmed from the study by Ikram et al. (2019), which admissibly used a Korean tool in the Pakistani context.

There were two parts of the questionnaire, formulated in an elementary language considering the needs of the construction industry of Pakistan. Part I of the questionnaire consisted of the respondent's general information. It included marital status, gender, qualification, designation, level of management, working experience in the construction industry, name of the firm, category of enlistment in Pakistan Engineering Council (PEC), and place of the head office (district). Part II was the main body of the questionnaire. It contained seventeen (17) questions related to determining and identifying critical elements impacting process quality of building construction projects during the design phase in Pakistan. 


\subsection{Data Collection}

Using multiple modes for data collection has been recognized as an established primary data collection approach. These modes include personal, cell phone, WhatsApp, email, and a blend of all methods. A list of valid design firms was obtained from the official website of the Pakistan Engineering Council (www.pec.org.pk). Most of the respondents were accessed through emails. 150 questionnaires were sent, and 71 were collected. From them, only 67 were filled correctly; thus, the response rate was $47.3 \%$, which is acceptable in the project management context. The sample size was 67, which was small; therefore, the deployment of Grey System Theory-based model was considered a suitable approach for data analysis. However, the Relative Importance Index (RII) was chosen for comparative analysis. The two techniques are discussed in the succeeding sections.

\subsection{Data Analysis}

IBM SPSS and Microsoft Excel are used for data analysis. The data analysis contains general characteristics of the respondents, summary of respondents, reliability analysis, apply correlation analysis model for determining the relationship among variables, prioritization of factors based on calculations of standard deviation, mean, and RII, and listing of top five essential elements which impart on process quality in Pakistani building construction projects while in designing stage.

\subsection{Sample Characteristics}

The questionnaires comprised of general characteristics of respondents and their firms.

3.4.1 Respondent characteristics: The characteristics of the respondents include their qualification, level of management and years of experience. The qualification of the majority of the respondents $(88 \%)$ participated in the survey was at least Bachelor's in Engineering, Civil Engineering or Project Management. However, some of the respondents were also the owners of the firms without a formal degree in construction-related disciplines. It shows that, in Pakistan, the ownership of a design firm does not necessarily lie with the people having qualifications related to constructionrelated disciplines. The majority of the respondents $(51 \%)$ held the position among the top-level management in their firms. Varied years of professional experience ranges from 1-5 years to more than 20 years, showing that highly skilled professionals from the design firms responded to the survey. A detailed breakdown of respondents' characteristics is presented in Table 1.

3.4.2 Design firm characteristics: A total of sixty-seven respondents in twenty districts of Pakistan responded to the survey. The list of these districts and the number of respondents from each district are shown in Table 2. It was realized that the majority of the respondents were from Punjab $(43 \%)$ and Sindh $(25 \%)$, which is because a large number of the design firms are based in the cities Karachi and Lahore.

\subsection{Reliability Analysis}

Before carrying out any other test, it is strongly recommended to judge the reliability of the collected data. Since the data gathered was based on 5-point Likert scale; therefore, to check the reliability Cronbach's alpha was used with the aid of IBM SPSS software (v.20). It was found reliable as above 0.75 in all cases; therefore, the collected data passed the reliability test. The formula for the estimation of Cronbach's alpha is given by (Cronbach, 1951)

$$
\alpha=\left(\frac{k}{k-1}\right)\left(1-\frac{\sum_{i=1}^{k} \sigma_{y i}^{2}}{\sigma_{x}^{2}}\right)
$$

where, $k$ implies number of scale items, $\sigma_{y i}^{2}$ implies to variance associated with item $i, \sigma_{x}^{2}$ implies to the variance related to the observed total scores. Alternatively, the formula may also be written as (Kopalle \& Lehmann, 1997), 
Table 1. Demographic profile of the respondents

\begin{tabular}{|c|c|c|c|c|}
\hline & Demographic & Number of Respondents & $\%$ & Cumulative \% \\
\hline \multirow{5}{*}{ 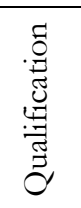 } & $\mathrm{BE}$ & 35 & 52 & 52 \\
\hline & MS & 24 & 36 & 88 \\
\hline & $\mathrm{PhD}$ & 4 & 6 & 94 \\
\hline & B. Arch & 2 & 3 & 97 \\
\hline & $\mathrm{MBA}$ & 2 & 3 & 100 \\
\hline \multirow{3}{*}{ 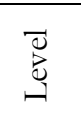 } & First Level Management & 23 & 34 & 34 \\
\hline & Middle Level Management & 10 & 15 & 49 \\
\hline & Top Level Management & 34 & 51 & 100 \\
\hline \multirow{5}{*}{ 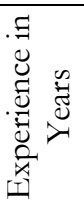 } & $1-5$ & 18 & 27 & 27 \\
\hline & $6-10$ & 15 & 22 & 49 \\
\hline & $11-15$ & 16 & 24 & 73 \\
\hline & $16-19$ & 8 & 12 & 85 \\
\hline & $20+$ & 10 & 15 & 100 \\
\hline \multirow{7}{*}{ 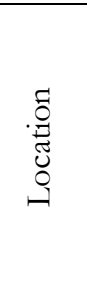 } & Federal Territory & 7 & 10 & 10 \\
\hline & Punjab & 29 & 43 & 53 \\
\hline & Sindh & 17 & 25 & 78 \\
\hline & KPK & 9 & 13 & 91 \\
\hline & Balochistan & 3 & 5 & 96 \\
\hline & Gilgit Baltistan & 1 & 2 & 98 \\
\hline & Azad Kashmir & 1 & 2 & 100 \\
\hline
\end{tabular}

$$
\alpha=\frac{k * \bar{c}}{\bar{v}+(k-1) \bar{c}}
$$

where, $k$ implies the number of scale items, $\bar{c}$ implies the mean of all covariances between items, and $\bar{v}$ implies mean variance of each item. The literature suggests that $\alpha \geq 0.7$ suffices the reliability of data.

\subsection{Factor Evaluation Techniques}

For ranking the factors, a set of popular and novel approaches have been used, i.e., the Relative Importance Index (RII) and the Grey Absolute Decision Analysis (GADA) methods.

3.6.1 Relative Importance Index (RII): The relative importance index determines the importance of various factors with respect to other comparable factors. RII is a traditional way of ranking factors in project management literature and has seen many applications. To evaluate delaying factors in India's construction projects, Rajgor et al. (2016) implemented RII. The scope of their investigation involved office, residential and high-rise buildings which they concluded that in material management, shortage of skilled laborers is the primary cause of delay. Gunduz and Ahsan (2018) used RII for the evaluation of construction safety factors. Alsuliman (2019) used RII for evaluating causes of delay in Saudi public construction projects. Aziz and Abdel-Hakam (2016) used RII to evaluate delay causing factors construction projects in Egypt. Sheikh et al. (2019) used RII for ranking the factors affecting process quality in Pakistani construction projects. Wu et al. (2019) used RII for the evaluation of factors in the off-site construction projects in China. In short, RII has garnered a lot of attention in project management literature for evaluating different factors.

RII of each factor was calculated using the formula given below (Fagbenle et al., 2004):

$$
R I I=\frac{\Sigma\left(P_{i} * U_{i}\right)}{N * n}
$$

where RII is Relative Importance Index, $P_{i}$ is the respondent's rating, $U_{i}$ is the number of respondents with an identical rating, $N$ is the sample size, and $n$ is the highest value on the Likert scale. 
Table 2. Location of design firms

\begin{tabular}{|c|c|c|c|}
\hline District & Number of Respondents & District & Number of Respondents \\
\hline Karachi & 15 & Wah Cant & 1 \\
\hline Lahore & 13 & Taxila & 1 \\
\hline Islamabad & 7 & Hyderabad & 1 \\
\hline Rawalpindi & 6 & Jamshoro & 1 \\
\hline Peshawar & 5 & Abbottabad & 1 \\
\hline Multan & 4 & Kohat & 1 \\
\hline Quetta & 3 & Swabi & 1 \\
\hline Faisalabad & 2 & Laki Marwat & 1 \\
\hline Gujranwala & 1 & Mirpur & Gilgit \\
\hline Bahawalpur & 1 & & \\
\hline
\end{tabular}

3.6.1 Grey Absolute Decision Analysis (GADA): Grey System Theory was established by Professor Deng in 1982, and since then, it has seen its application in a wide range of areas, e.g., healthcare (Aydemir \& Sahin, 2019; Quartey-Papafio et al., 2019), environmental sustainability (Shahzad et al., 2020), supply chain (Diba \& Xie, 2019; Mahmoudi et al., 2021 a; 2021b), tourism (Javed et al., 2020a) energy and emissions (Ofosu-Adarkwa et al., 2020; Du et al., 2019; Xie et al., 2020), information systems (Esangbedo et al., 2021), engineering (Abifarin et al., 2021), economics (Camelia, 2015), etc. Also, it has seen applications in project management (Javed \& Liu, 2019; Mahmoudi et al., 2020; 2021c). Studies have reported that Grey System Theory based models are particularly useful when data is small or insufficient (Javed et al., 2020b), as is the case in the current study. Considering the small data size in our research, we decided to use a Grey System Theory-based approach. Grey Absolute Decision Analysis (GADA) model, proposed by Javed et al. (2020c), is a new development in the theory of multi-attribute decision making $(\mathrm{MADM})$ and is a kind of breakthrough as, unlike conventional MADM methods, it does not require normalization of data. Thus, the model is practically dimensionless and convenient to use. As mentioned earlier, the key advantage of this method lies in its simplicity and independence over the dimensions of the criteria.

The GADA method involves a procedure to estimate GADA Indexes and GADA Weights. If there are $M$ criteria $(C(k) ; \mathrm{k}=1,2, \ldots, \mathrm{M}), N$ respondents $\left(\mathrm{E}_{\mathrm{i}} ; \mathrm{i}=1,2, \ldots, N\right)$ and $S$ alternatives $\left(\mathrm{A}_{\mathrm{j}}\right.$; $\mathrm{j}=1,2, \ldots, S)$ then the GADA Indexes $\grave{r}_{j}$ and GADA Weights $\grave{R}_{j}$ are given by (Javed et al., 2020c),

$$
\grave{R}_{j}=\frac{\grave{r}_{j}}{\sum_{j=1}^{s} \grave{r}_{j}}
$$

where,

$$
\grave{r}_{j}=\left(\prod_{j=1}^{s} r_{j}^{\alpha_{i}}\right)^{1 / \Sigma_{i=1}^{N} \alpha_{i}}
$$

where $r$ represents observations and $\alpha$ is Javed's parameter and $\varepsilon$ is Liu's absolute degree of grey incidence, respectively given by

$$
\alpha_{i}=\frac{1}{N}\left(\varepsilon_{i 1}+\varepsilon_{i 2} \ldots+\varepsilon_{i N}\right)
$$

and,

$$
\varepsilon_{i j}=\frac{1+\left|s_{i}\right|+\left|s_{j}\right|}{1+\left|s_{i}\right|+\left|s_{j}\right|+\left|s_{i}-s_{j}\right|}
$$

where,

$$
\left|s_{i}\right|=\left|\sum_{k=2}^{n-1} x_{i}^{0}(k)+\frac{1}{2} x_{i}^{0}(n)\right|,\left|s_{j}\right|=\left|\sum_{k=2}^{n-1} x_{j}^{0}(k)+\frac{1}{2} x_{j}^{0}(n)\right|,
$$


Table 3. RII and GADA rankings of design phase elements

\begin{tabular}{|c|l|c|c|c|c|c|}
\hline $\begin{array}{c}\text { Factor } \\
\text { No. }\end{array}$ & \multicolumn{1}{|c|}{ Factor* } & RII & $\begin{array}{c}\text { Rank } \\
\text { (RII) }\end{array}$ & $\begin{array}{c}\text { GADA } \\
\text { Index }\end{array}$ & $\begin{array}{c}\text { GADA } \\
\text { Weight }\end{array}$ & $\begin{array}{c}\text { Rank } \\
\text { (GADA) }\end{array}$ \\
\hline F1 & $\begin{array}{l}\text { Level of cooperation of design } \\
\text { professionals }\end{array}$ & 0.800 & 8 & 3.927 & 0.061 & 8 \\
\hline F2 & $\begin{array}{l}\text { Extent of teamwork of parties } \\
\text { participating in the design phase }\end{array}$ & 0.836 & 3 & 4.086 & 0.063 & 2 \\
\hline F3 & $\begin{array}{l}\text { Level of management leadership in } \\
\text { promoting quality }\end{array}$ & 0.788 & 11 & 3.854 & 0.060 & 11 \\
\hline F4 & $\begin{array}{l}\text { Level of management commitment to } \\
\text { continuous quality improvement }\end{array}$ & 0.806 & 7 & 3.935 & 0.061 & 7 \\
\hline F5 & Use of statistical methods & 0.651 & 16 & 3.076 & 0.048 & 16 \\
\hline F6 & Existence of feedback system & 0.734 & 14 & 3.481 & 0.054 & 14 \\
\hline F7 & Constructability of the design & 0.833 & 4 & 4.075 & 0.063 & 3 \\
\hline F8 & Educational background of designers & 0.800 & 8 & 3.898 & 0.060 & 9 \\
\hline F9 & Extent of designers training & 0.830 & 5 & 4.063 & 0.063 & 4 \\
\hline F10 & Selection of appropriate design firm & 0.827 & 6 & 4.021 & 0.062 & 6 \\
\hline F11 & Characteristics of office practices & 0.719 & 15 & 3.458 & 0.054 & 15 \\
\hline F12 & Briefing of owner & 0.800 & 8 & 3.896 & 0.060 & 10 \\
\hline F13 & Budget allocated for design & 0.770 & 13 & 3.685 & 0.057 & 13 \\
\hline F14 & $\begin{array}{l}\text { Appropriateness of project } \\
\text { specifications }\end{array}$ & 0.839 & 2 & 4.048 & 0.063 & 5 \\
\hline F15 & Quality of codes and standards & 0.881 & 1 & 4.344 & 0.067 & 1 \\
\hline F16 & Characteristics of drafting practices & 0.776 & 12 & 3.810 & 0.059 & 12 \\
\hline F17 & Personalities of the participants & 0.615 & 17 & 2.892 & 0.045 & 17 \\
\hline$*$ The factors are adapted from Arditi and Gunaydin $(1997 ; 1998 ; 1999)$. & & & & 7 \\
\hline
\end{tabular}

$$
\left|s_{i}-s_{j}\right|=\left|\sum_{k=2}^{n-1}\left(x_{i}^{0}(k)-x_{j}^{0}(k)\right)+\frac{1}{2}\left(x_{i}^{0}(n)-x_{j}^{0}(n)\right)\right|
$$

For further details about the model, its parameters, and its properties, Javed et al. (2020c) can be consulted.

\section{Results and discussion}

The results of the ranking analysis of factors by relative importance index (RII) and Grey Absolute Decision Analysis (GADA) are shown in Table 3. The overall ranking by the two models reflects differently. The highest and lowest RII are 0.881 and 0.615 which corresponds to the quality of codes and standards and participants' personality, respectively. Similarly, the highest and lowest weight by GADA is 0.673 and 0.0448 but equally corresponds to the quality of codes and standards and the personality of participants, respectively. Therefore, an agreed consensus by the two models has been established to distinguish the significant effect on process quality of building projects in Pakistan.

After ranking the elements that impact the process quality of building projects in Pakistan during the design phase, the top five (5) critical elements were identified. Figure 1 shows top five critical success factors identified through the two techniques.

Following factor number 15, GADA demonstrates the teamwork of participating parties in the design phase and the constructability of the design as the $2^{\text {nd }}$ and $3^{\text {rd }}$ key factors influencing process quality in the design phase during construction projects in Pakistan. Meanwhile, RII rankings say otherwise, apart from the only similarities it has with GADA. For decision-making purposes, a clear preference or priority must be drawn. Grey method in its natural state revolves around uncertainty as to the fundamental analysis approach, thereby having a strong advantage of RII, 


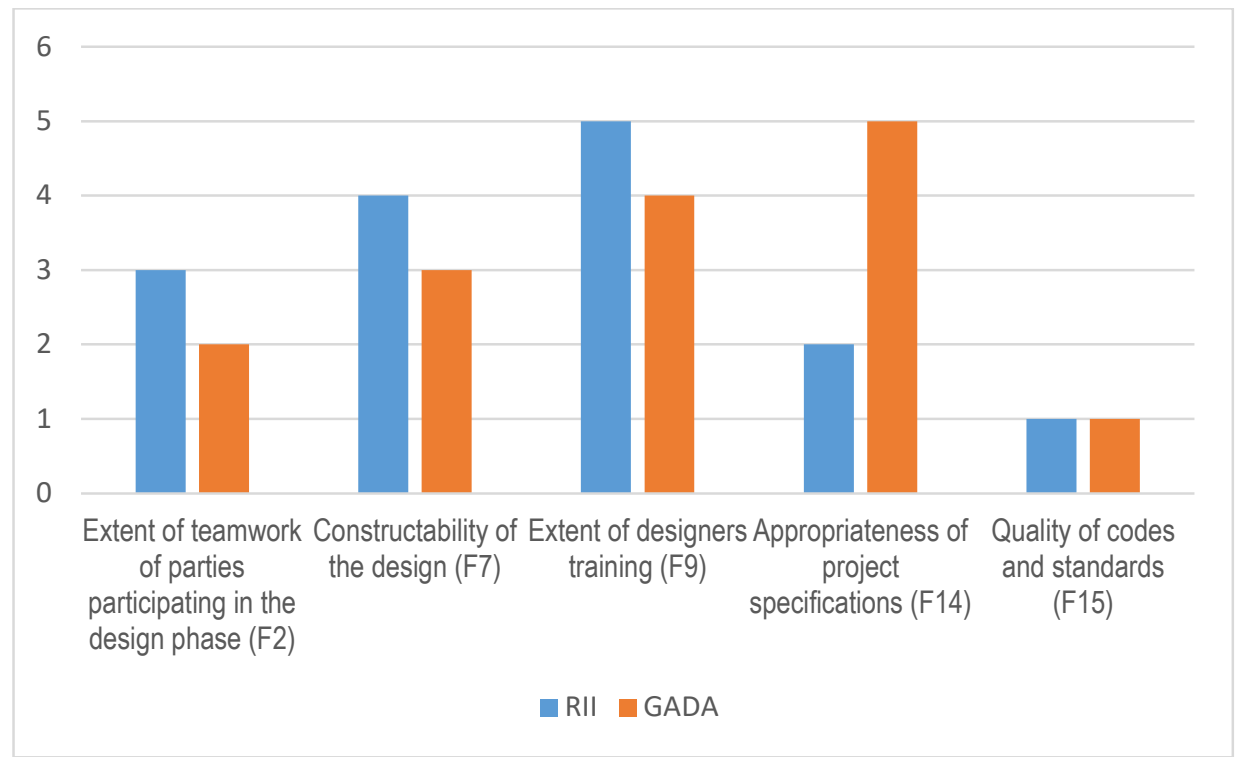

Figure 1. Top five critical success factors in process quality

which relies on a conservative approach. For that matter, it is suggested to use grey absolute decision analysis in the decision-making process when the decision-making process contains uncertainty. However, both approaches reveal the quality of codes and standards to be the most critical factor in the process quality of construction projects of Pakistan during the building design phase; thus the finding can be accepted with confidence.

Even though the list of top five factors is comparable, the relative position of factors is not entirely the same. One may ask, 'why the critical elements of RII and GADA have obvious differences?' Firstly, RII is a simple approach if one compares it with GADA, which is a more comprehensive approach of ranking parameters. Secondly, different factors may influence ranks. For instance, a study by Palczewski and Sałabun (2019) reports how just by changing the type of normalization method, rankings thus obtained can be very different. Mulliner et al. (2016) showed how different decision-making models could reveal different, and sometimes contradictory ranks. This is a well-known dilemma of decision-making under multiple attributes, and resolving it is beyond the scope of the current study.

\section{Conclusion}

The construction industry is an essential function for the progress of any country in this highly competitive business world. This industry contributes to the country's operational, economic development, and growth and cannot be neglected on any occasion. The design phase is one of the significant areas in the construction industry. Quality is paramount in the design. Therefore, the scope of this study was to evaluate the most critical elements in-process quality of construction building projects in Pakistan during the design phase to enable better performance improvement. The established data was accumulated through respondents registered with Pakistan Engineering Council. The constituted factors that are realized to affect the quality were successfully graded by RII and GADA models. The results revealed that the quality of codes and standards ranked superior for both models among the topmost five factors that critically impact greatly on the process quality of construction building projects in Pakistan. The remaining factors jumbled up at different positions by the two models. Nevertheless, preference is given to grey absolute degree analysis due to its strength in analyzing uncertainty systems, while RII draws evaluation based on exact presentation of data values.

Accordance with the results, the positive contribution of teamwork, especially for designing the firm structure and completing the project within a defined time frame, is considered an important aspect. This aspect revolves around determining the constructability with the proper support of 
designer training that leads to the quality process. This study ultimately reflected the research hypotheses, supported by the data, and led us to meaningful results.

It is highly recommended that there is still a need for improvement to develop the proper codes or standards concerning Pakistani culture. It is advised that Pakistani culture, business norms, and ethics should be attuned to the local designs and conditions. The construction sector can assist in this regard by executing research and surveys in this field which might help evolve comprehensive national codes and standards for buildings. The development of building codes and standards promotes project completion. One other important factor to consider is that the designers should emphasize project specifications, especially while adopting them from other projects. The local conditions of the area, requirements of the owner, and agreement of all parties to various definitions and terminologies must be given considerable importance. Advanced database and information system technologies should be used to minimize the chances of errors.

The study was limited to the design phase of firms registered under PEC in the construction sector, and as well the response rate from respondents was approximately half of the expected feedback. Nevertheless, analytical results prove to be reliable and efficient for good decisionmaking by project managers and all stakeholders at large. This research study may help future researchers to develop a comprehensive process quality framework for Pakistani building projects. Studies must be conducted to identify critical factors influencing process quality in other phases (construction, operation \& maintenance phases) of building projects in Pakistan. Future studies may also be carried out to check the impact of process quality on time and the cost of building projects. This study encompasses building projects only. A similar study can be conducted to identify the critical factors that impact the process quality of roads, infrastructure, and other types of projects relevant to the construction industry of Pakistan.

\section{References}

Abifarin, J. K. (2021). Taguchi grey relational analysis on the mechanical properties of natural hydroxyapatite: effect of sintering parameters. The International Journal of Advanced Manufacturing Technology, 117, 49-57. https://doi.org/10.1007/s00170-021-07288-9

Alsuliman, J. A. (2019). Causes of delay in Saudi public construction projects. Alexandria Engineering Journal, 58(2), 801-808. https://doi.org/10.1016/j.aej.2019.07.002

Amar, K., \& Mohd Zain, Z. (2002). Barriers to implementing TQM in Indonesian manufacturing organizations. TQM Magazine, 14(6), 367-372. https://doi.org/10.1108/09544780210447474

Arditi, D., \& Gunaydin, H. M. (1997). Total quality management in the construction process. International Journal of Project Management, 15(4), 235-243. https://doi.org/10.1016/S0263-7863(96)00076-2

Arditi, D., \& Gunaydin, H. M. (1998). Factors That Affect Process Quality in the Life Cycle of Building Projects. Journal of Construction Engineering and Management, 124(3), 194-203. https://doi.org/10.1061/(ASCE)0733-9364(1998)124:3(194)

Arditi, D., \& Gunaydin, H. M. (1999). Perceptions of Process Quality in Building Projects. Journal of Management in Engineering, 15(2), 43-53. https://doi.org/10.1061/(ASCE)0742-597X(1999)15:2(43)

Aydemir, E. and Sahin, Y. (2019). Evaluation of healthcare service quality factors using grey relational analysis in a dialysis center. Grey Systems: Theory and Application, 9(4), pp. 432-448. https://doi.org/10.1108/GS01-2019-0001

Aziz, R. F., \& Abdel-Hakam, A. A. (2016). Exploring delay causes of road construction projects in Egypt. Alexandria Engineering Journal, 55(2), 1515-1539. https://doi.org/10.1016/j.jare.2012.11.005

Banihashemi, S., Hosseini, M. R., Golizadeh, H., \& Sankaran, S. (2017). Critical success factors (CSFs) for integration of sustainability into construction project management practices in developing countries. International Journal of Project Management, 35(6), 1103-1119. https://doi.org/10.1016/j.ijproman.2017.01.014

Batool, A., \& Abbas, F. (2017). Reasons for delay in selected hydro-power projects in Khyber Pakhtunkhwa (KPK), Pakistan. Renewable \& Sustainable Energy Reviews, 73(73), 196-204. https://doi.org/10.1016/j.rser.2017.01.040

Belout, A., \& Gauvreau, C. (2004). Factors influencing project success: the impact of human resource management. International Journal of Project Management, 22(1), 1-11. https://doi.org/10.1016/S02637863(03)00003-6 
Bieger, I., \& Carvalho, C. (2015). Design Project for the Resignification of Peniche's Bobbin Lace. Procedia Manufacturing, 3(Ahfe), 6565-6570. https://doi.org/10.1016/j.promfg.2015.07.959

Burati Jr, J. L., Farrington, J. J., \& Ledbetter, W. B. (1992). Causes of quality deviations in design and construction. Journal of Construction Engineering and Management, 118(1), 34-49. https://doi.org/10.1061/(ASCE)0733-9364(1992)118:1(34)

Camelia, D. (2015). Grey systems theory in economics - a historical applications review. Grey Systems: Theory and Application, 5(2), 263-276. https://doi.org/10.1108/GS-05-2015-0018

Carayon, P., Hoonakker, P., Smith, M. J. (2012). Chapter 18 - Human Factors in Organizational Design and Management. In: Handbook of Human Factors and Ergonomics (4 ${ }^{\text {th }}$ ed.). John Wiley \& Sons, Inc. https://doi.org/10.1002/9781118131350.ch18

Chan, A. P., Wong, F. K., \& Lam, P. T. (2006). Assessing quality relationships in public housing: an empirical study. International Journal of Quality \& Reliability Management, 23(8), 909-927. https://doi.org/10.1108/02656710610688130

Chung, H. W. (2002). Understanding quality assurance in construction: A Practical Guide to ISO 9000 for Contractors. Routledge.

Cronbach, L. J. (1951). Coefficient alpha and the internal structure of tests. Psychometrika, 16(3), 297-334. https://doi.org/10.1007/BF02310555

Diba, S., \& Xie, N. (2019). Sustainable supplier selection for Satrec Vitalait Milk Company in Senegal using the novel grey relational analysis method. Grey Systems: Theory and Application, 9(3), 262-294. https://doi.org/10.1108/GS-01-2019-0003

Dizdar, S. İ. (2015). Architectural Education, Project Design Course and Education Process Using Examples. Procedia - Social and Behavioral Sciences, 176, 276-283. https://doi.org/10.1016/j.sbspro.2015.01.472

Du, J.-L., Liu, Y. \& Forrest, J.Y.-L. (2019). An interactive group decision model for selecting treatment schemes for mitigating air pollution. Environmental Science and Pollution Research, 26, 18687-18707. https://doi.org/10.1007/s11356-019-05072-7

Esangbedo, M. O., Bai, S., Mirjalili, S., \& Wang, Z. (2021). Evaluation of human resource information systems using grey ordinal pairwise comparison MCDM methods. Expert Systems With Applications, 182, 115151. https://doi.org/10.1016/j.eswa.2021.115151

Fagbenle, O. I., Adeyemi, A. Y., \& Adesanya, D. A. (2004). The impact of non-financial incentives on bricklayers' productivity in Nigeria. Construction Management and Economics, 22(9), 899-911. https://doi.org/10.1080/0144619042000241262

Farooqui, R. U., Masood, R., \& Junaid, A. J. (2008). Assessing the Viability of Total Quality Management Implementation in Contracting firms of Pakistani Construction industry. Paper presented at the First International Conference on Construction in Developing Countries (ICCIDC-I) "Advancing and Integrating Construction Education, Research \& Practice", Karachi, Pakistan.

Gebhardt, K., Riel, A., \& Maes, T. (2019). Corporate Entrepreneurship in Complex Organisations: Towards a Holistic Decision Aid Tool Set to Analyse and Plan Innovative Design Projects. Procedia CIRP, 84, 644-649. https://doi.org/10.1016/j.procir.2019.04.312

Gunduz, M., \& Ahsan, B. (2018). Construction safety factors assessment through Frequency Adjusted Importance Index. International Journal of Industrial Ergonomics, 64, 155-162. https://doi.org/10.1016/j.ergon.2018.01.007

Heravitorbati, A., Coffey, V., \& Trigunarsyah, B. (2011). Assessment of requirements for establishment of a framework to enhance implementation of quality practices in building projects. International Journal of Innovation, Management, and Technology, 2(6), 465-470. https://doi.org/10.7763/IJIMT.2011.V2.177

Huirne, R. B. M., Harsh, S. B., \& Dijkhuizen, A. A. (1997). Critical success factors and information needs on dairy farms: the farmer's opinion. Livestock Production Science, 48(3), 229-238. https://doi.org/10.1016/S0301-6226(97)00030-4

Ikram, M., Zhou, P., Shah, S. A. A., \& Liu, G. Q. (2019). Do environmental management systems help improve corporate sustainable development? Evidence from manufacturing companies in Pakistan. Journal of Cleaner Production, 226, 628-641. https://doi.org/10.1016/j.jclepro.2019.03.265

Jaber, M. Y., Glock, C. H., \& Zanoni, S. (2018). A Learning Curve with Improvement in Process Quality. IFAC-PapersOnLine, 51(11), 681-685. https://doi.org/10.1016/j.ifacol.2018.08.397

Javed, S. A., \& Liu, S. (2018). Evaluation of Outpatient Satisfaction and Service Quality of Pakistani Healthcare Projects: Application of a novel Synthetic Grey Incidence Analysis model. Grey Systems: Theory and Applications, 8(4), 462-480. https://doi.org/10.1108/GS-04-2018-0018 
Javed, S. A., \& Liu, S. (2019). Bidirectional Absolute GRA/GIA model for Uncertain Systems: Application in Project Management. IEEE Access, 7(1), 60885-60896. https://doi.org/10.1109/ACCESS.2019.2904632

Javed, S. A., Ikram, M., Tao, L., \& Liu, S. (2020a). Forecasting Key Indicators of China's Inbound and Outbound Tourism: Optimistic-Pessimistic Method. Grey Systems: Theory and Application, 11(2), 265287. https://doi.org/10.1108/GS-12-2019-0064

Javed, S. A., Liu, S., Mahmoudi, A., \& Nawaz, M. (2019). Patients' Satisfaction and Public and Private Sectors' Healthcare Service Quality in Pakistan: Application of Grey Decision Analysis approaches. International Journal of Health Planning and Management, 34(1), e168-e182. https://doi.org/10.1002/hpm.2629

Javed, S. A., Mahmoudi, A., \& Liu, S. (2020c). Grey Absolute Decision Analysis (GADA) method for Multiple Criteria Group Decision Making under Uncertainty. International Journal of Fuzzy Systems, 22(4), 1073-1090. https://doi.org/10.1007/s40815-020-00827-8

Javed S. A, Zhu, B., \& Liu, S. (2020b). Forecast of Biofuel Production and Consumption in Top $\mathrm{CO}_{2}$ Emitting Countries using a novel grey model. Journal of Cleaner Production, 276, 123977. https://doi.org/10.1016/j.jclepro.2020.123997

Jensen, M., \& Drozdenko, R. (2008). The changing price of brand loyalty under perceived time pressure. Journal of Product \& Brand Management. https://doi.org/10.1108/10610420810864720

Juran, J. M. (1988). Juran's quality control handbook (4th ed.): McGraw-Hill, New York.

Kerzner, H. (2014). Project management best practices: Achieving global excellence (4 ${ }^{\text {th }}$ ed.). John Wiley \& Sons. https://doi.org/10.1002/9781118835531

Khan, R. A. (2008). Role of Construction Sector in Economic Growth: Empirical Evidence from Pakistan. Paper presented at the First International Conference on Construction In Developing Countries (ICCIDCI) "Advancing and Integrating Construction Education, Research \& Practice", Karachi, Pakistan.

Kopalle, P. K., \& Lehmann, D. R. (1997). Alpha Inflation? The Impact of Eliminating Scale Items on Cronbach's Alpha. Organizational Behavior and Human Decision Processes, 70(3), 189-197.

Lee, P. M. (2002). Sustaining business excellence through a framework of best practices in TQM. The TQM Magazine, 13(3), 142-149. https://doi.org/10.1108/09544780210425883

Li, Y., Song, H., Sang, P., Chen, P.-H., \& Liu, X. (2019). Review of Critical Success Factors (CSFs) for green building projects. Building and Environment, 158, 182-191. https://doi.org/10.1016/j.buildenv.2019.05.020

Low, S. P., \& Goh, K. H. (1994). Construction quality assurance: problems of implementation at infancy stage in Singapore. International Journal of Quality \& Reliability Management, 11(1), 23-37. https://doi.org/10.1108/02656719410049475

Mahmoudi, A., Deng, X., Javed, S. A., \& Zhang, N. (2021b). Sustainable Supplier Selection in Megaprojects through Grey Ordinal Priority Approach. Business Strategy and The Environment, 30, 318-339. https://doi.org/10.1002/bse.2623

Mahmoudi, A., Javed, S. A., \& Mardani, A. (2021a). Gresilient Supplier Selection through Fuzzy Ordinal Priority Approach: Decision-making in Post-COVID era. Operations Management Research. http://dx.doi.org/10.1007/s12063-021-00178-z

Mahmoudi, A., Javed, S. A., Liu, S., \& Deng, X. (2020). Distinguishing Coefficient driven Sensitivity Analysis of GRA Model for Intelligent Decisions: Application in Project Management. Technological and Economic Development of Economy, 26(3), 621-641. https://doi.org/10.3846/tede.2020.11890

Mahmoudi, A., Javed, S.A., \& Deng, X. (2021c). Earned Duration Management under Uncertainty. Soft Computing. https://doi.org/10.1007/s00500-021-05782-6

Maqbool, R., \& Sudong, Y. (2018). Critical success factors for renewable energy projects; empirical evidence from Pakistan. Journal of Cleaner Production, 195, 991-1002. https://doi.org/10.1016/j.jclepro.2018.05.274

Mashwama, N., Aigbavboa, C., \& Thwala, D. (2017). An Assessment of the Critical Success factor for The Reduction of Cost of Poor Quality in Construction Projects in Swaziland. Procedia Engineering, 196, 447-453. https://doi.org/10.1016/j.proeng.2017.07.223

Memon, N. A., Khatri, K. L., \& Memon, A. B. (2013). TQM in Construction and Manufacturing Companies of Pakistan: A Case Study. Mehran University Research Journal of Engineering \& Technology, 32(2), 261-268.

Militaru, M., Ungureanu, G., \& Crețu, A. Ş. C. (2013). The Prospects of Implementing the Principles of Total Quality Management (TQM) in Education. Procedia - Social and Behavioral Sciences, 93, 1138-1141. https://doi.org/10.1016/j.sbspro.2013.10.003 
Mourtzis, D., Boli, N., Alexopoulos, K., Pittaro, P., \& Terreno, A. (2018). An industrial product-service system approach for laser process quality control. Procedia CIRP, 75, 403-408. https://doi.org/10.1016/j.procir.2018.04.052

Mujumdar, P., \& Maheswari, J. U. (2018). Design iteration in construction projects - Review and directions. Alexandria Engineering Journal, 57(1), 321-329. https://doi.org/10.1016/j.aej.2016.12.004

Mulliner, E., Malys, N., \& Maliene, V. (2016). Comparative analysis of MCDM methods for the assessment of sustainable housing affordability. Omega, 59, 146-156. https://doi.org/10.1016/j.omega.2015.05.013

Nagasaku, C., \& Oda, M. (1965). Planning and execution of quality control. JUSE Press, Tokyo.

Ostenfeld, E. (1994). Aristotle on the Good Life and Quality of Life, In: Nordenfelt L. (eds) Concepts and Measurement of Quality of Life in Health Care. European Studies in Philosophy of Medicine 1, vol 47. Springer, Dordrecht. DOI: https://doi.org/10.1007/978-94-015-8344-2_2

Palczewski, K., \& Sałabun, W. (2019). Influence of various normalization methods in PROMETHEE II: an empirical study on the selection of the airport location. Procedia Computer Science, 159, 2051-2060. https://doi.org/10.1016/j.procs.2019.09.378

Quartey-Papafio, T. K., Liu, S., \& Javed, S. (2019). Grey relational evaluation of impact and control of malaria in Sub-Saharan Africa. Grey Systems: Theory and Application, 9(4), 415-431. https:/ /doi.org/10.1108/GS06-2019-0020

Rahmat, R. A. A. O. K., Yatim, M. Y. M., Maulud, K. N. A., Yusoff, N. I. M., \& Mutalib, A. A. (2012). The Effectiveness of basic Design Project (Cornerstone) in Students' Competency Development. ProcediaSocial and Behavioral Sciences, 60, 56-60. https://doi.org/10.1016/j.sbspro.2012.09.346

Rajgor, M. Paresh, C. Dhruv, P. Dhrmesh, B. (2016). RII \& IMPI: Effective Techniques for Finding Delay in Construction Project. International Research Journal of Engineering and Technology, 3(1), 1173-1177.

Roos, A., Graham, R. L., Hektor, B., \& Rakos, C. (1999). Critical factors to bioenergy implementation. Biomass \& Bioenergy, 17(2), 113-126. https://doi.org/10.1016/S0961-9534(99)00028-8

Sahoo, S., \& Yadav, S. (2018). Total Quality Management in Indian Manufacturing SMEs. Procedia Manufacturing, 21, 541-548. https://doi.org/10.1016/j.promfg.2018.02.155

Shahzad, M., Qu, Y., Javed, S. A., Zafar, A. U., \& Rehman, S. U. (2020). Relation of Environment Sustainability to CSR and Green Innovation: A Case of Pakistani Manufacturing Industry. Journal of Cleaner Production, 253, 119938. https://doi.org/10.1016/j.jclepro.2019.119938

Sheikh, A. H. A., Ikram, M., Ahmad, R. M., Qadeer, H., \& Nawaz, M. (2019). Evaluation of key factors influencing process quality during construction projects in Pakistan. Grey Systems: Theory and Application, 9(3), 321-335. https://doi.org/10.1108/GS-01-2019-0002

Small, E. P., \& Al, K. (2017). Benchmarking Performance of TQM Principals in Electrical Subcontracting in Dubai: A Case Study. Procedia Engineering, 196(June), 622-629. https://doi.org/10.1016/j.proeng.2017.08.050

Stalin, J. (1976). Dialectical and Historical Materialism (Problems of Leninism). Peking: Foreign Languages Press.

Strain, J. D., \& Preece, D. A. (1999). Project management and the integration of human factors in military system procurement. International Journal of Project Management, 17(5), 283-292. https://doi.org/10.1016/S0263-7863(98)00044-1

Stritter, W., Rutert, B., Längler, A., Eggert, A., Holmberg, C., \& Seifert, G. (2018). Integrative care for children with cancer. Project design for the development of an integrative care programme for use in paediatric oncology. Complementary Therapies in Medicine, 41(April), 247-251. https://doi.org/10.1016/j.ctim.2018.10.005

Temtime, Z. T. (2003). The moderating impacts of business planning and firm size on total quality management practices. The TQM Magazine, 15(1), 52-60. https://doi.org/10.1108/09544780310454457

Tjell, J., \& Bosch-Sijtsema, P. M. (2015). Visual Management in Mid-sized Construction Design Projects. Procedia Economics and Finance, 21(2014), 193-200. https://doi.org/10.1016/s2212-5671(15)00167-7

Ulewicz, R., \& Nový, F. (2019). Quality management systems in special processes. Transportation Research Procedia, 40, 113-118. https://doi.org/10.1016/j.trpro.2019.07.019

Wu, P., Xu, Y., Jin, R., Lu, Q., Madgwick, D., \& Hancock, C. M. (2019). Perceptions towards risks involved in off-site construction in the integrated design \& construction project delivery. Journal of Cleaner Production, 213, 899-914. https://doi.org/10.1016/j.jclepro.2018.12.226

Xie, W., Wu, W.-Z., Liu, C., \& Zhao, J. (2020). Forecasting annual electricity consumption in China by employing a conformable fractional grey model in opposite direction. Energy, 202, 117682. https://doi.org/10.1016/j.energy.2020.117682 